\title{
When duty house calls
}

Lealani Mae Y. Acosta, MD

Neurology ${ }^{\circledR}$ 2020;95:973-975. doi:10.1212/WNL.0000000000010864

\section{Correspondence}

Dr. Acosta

lealani.mae.acosta@

vumc.org

The phrase "house call" conjures up nostalgia for an era most of us have never experienced, painted with cheerful and tender Norman Rockwell-style strokes. The avuncular physician, likely a man, clad in a crisp suit, with a capacious leather satchel filled with tinctures of nowillegal substances clinking in glass bottles. The cherubic child clad in a white nightgown, tucked under a patchwork quilt, curls against the pillow, clutching a beloved doll. The worried parent, likely a woman, hovering over the bedside with a cool compress against the fevered forehead.

While I have only sepia photos and phonograph recordings to inform me of such a time, my patient Mary actually lived through it. She was born in the thick of such a period, in the 1930s, an era when $40 \%$ of physician encounters were house calls. ${ }^{1}$ When I had established care for dementia in her 80s, she still had a razor wit, mischievous grin, and twinkling blue eyes. I could tell she had been a kind, but firm, schoolteacher, likely not one to have put up with tomfoolery.

Her Alzheimer disease had advanced over the years: in conjunction with her longstanding caregiver, we had optimized therapies and she had no other complications beyond the expected cognitive impairment and apraxia. Medical comorbidities and age had rendered her frail, so she came to her last few visits in a wheelchair, accompanied by her attentive caregiver, who did much of the talking. My last clinic visit with her was in January. She could tell me her name, but was not otherwise oriented. Her responses were limited to a few words. Her use of an acetylcholinesterase inhibitor had led to pesky rhinorrhea that we couldn't counter, so she was constantly wiping her nose. The caregiver and I discussed at length the risk-benefit ratio of discontinuing her Alzheimer medications. Given her advanced state and side effects, with more palliative care in mind, we agreed a trial backing off of them would be reasonable.

Because transporting her to the clinic was so difficult, we decided that any follow-up would be as-needed. I was sad to be discharging her because I'd grown fond of her. I wasn't sure how much of what we were discussing had registered. As I was saying good-bye, her parting "gift" to me was a sly wink and that familiar twinkle in her eye that let me know she was still paying attention. I did not think that I would ever see her again.

A couple of months into our state's COVID-19 pandemic restrictions, and 4 months since our last visit, I received a message from her caregiver. Together with her PCP, they had carefully weaned off her medications as I had instructed, but she had developed new symptoms that they weren't sure were related to the cessation. She had been relatively immobile for some time, but somewhat suddenly had developed contractures in all her limbs. Moving her for bathing and dressing was painful. She was also increasingly more somnolent and less responsive. Could this all be related to stopping the donepezil and memantine, or secondary to advanced Alzheimer's?

I was familiar with the somnolence and decreased verbal output in advanced dementia, but not the contractures, so I started reviewing the literature. I'd seen a fair number of Alzheimer patients who developed parkinsonism in clinic, which could lead to rigidity, but by the time their dementia was this advanced, they usually had stopped coming for follow-up visits. I read several articles about the stiffness and contractures that can accompany late-stage Alzheimer's, compounded by lack of mobility from being chair- or bed-bound. I could not find any connection with the discontinuation of the medications we had stopped. 
We discussed options for re-evaluation. Bundling her up to the clinic was not one of them. Telemedicine was what had originally been raised, but I would be hampered in my ability to assess certain things on her exam, like tone and reflexes. The nascent thought was still forming as I blurted out, "I would need to check with the clinic supervisor about this, but would you be okay if I came to do a house call?"

House calls have a storied history. The treatment of illness has varied in location, ranging from early hospitals as far back as $2000 \mathrm{BC}$ in Mesopotamia to house calls during the time of Hippocrates in 4th century BC Greece. ${ }^{2}$ Physicians over the centuries have been courageous and ingenious in their means of attending to patients, particularly in times of pandemic. A striking example of this is the during the 14th century bubonic plague outbreak in Venice, most notable for the iconic plague doctor outfit. This uniform included leather gloves, a waxed overcoat, and a mask with a protruding beak, stuffed with aromatics to ward off the miasma of illness. The plague doctor carried a cane, used in part to gauge a safe distance at which to examine patients: even then, they practiced physical distancing at the bedside of each patient. While a number of physicians fled the city in self-preservation, others stayed behind. ${ }^{3}$ We see more modern examples of similarly dedicated health care workers, starting with the 1918 Spanish flu epidemic, when house calls were omnipresent in the US, to more recent outbreaks like Ebola, ${ }^{4}$ and now, during COVID-19.

With the shift towards hospitals and clinics in the latter part of the 20th century, house calls are most commonly used for elderly patients who have difficulty leaving home, though this is still the minority of medical encounters. Visits tend to cater to older patients, those more likely to experience hospitalization, and are in end-of-life care. ${ }^{5}$ My instinct to go to the patient's house, while not unprecedented, is still uncommon.

I had no idea if anybody from our academic neurology practice even did house calls: within our hospital system, home health therapies, sure, or the PRN concierge medicine advertisements I'd seen on the side of city buses, but not a neurologist going to a patient's home. I emphasized it was their decision as to whether I came in person, knowing that they might not want to run the risk of having somebody who works in the hospital entering the home. The caretaker said they would think it over and let me know while I checked with the clinic.

A few emails, telephone calls, and days later, I found myself driving over to her home one afternoon. I'd wiped off every neurologic instrument and my doctor's bag before I left the clinic and changed into fresh scrubs and a mask, since I'd spent the morning at the hospital. Her caretaker greeted me and ushered me indoors. Mary was sleeping, curled on her side, almost in a fetal position, clad in innocent white as pristine as the sheets on her hospital bed. Beloved religious items and stuffed animals lined the bookshelves in her room, interspersed with purple paper flowers that bloomed on her walls. I spoke with her caretaker and her PCP, who also happened to be there, as we consulted and convened at safe social distances around her bedside.

When I finally tried to rouse her, I gave my tools another cleaning and doused my hands in sanitizer, gently rubbing her shoulder and calling her name loudly; it took several trials to get her to open her eyes. She peered at me through half-closed lids-I knew my appearance would be unusual with the mask shielding my face, but I spoke loudly and hoped she might remember my voice. She moved her eyes in the cardinal directions when I asked her to, but did not answer any of my other commands, such as to protrude her tongue or smile, even with demonstration as I temporarily pulled down my mask. Her eyes widened and brightened appreciably as she took stock of the other, more familiar, faces in the room. I could not identify any clearly parkinsonian signs on exam. Her drawn face winced as I carefully moved each of her limbs. I didn't want our final interaction to be one of discomfort, so I pulled out all my tricks to get her to smile, making silly faces and asking about her favorite brother that she'd told me about on previous visits. Nothing. I pulled out my mobile and showed her pictures of my 2 toddlers, which finally garnered a grin and a coo.

I spoke with both her caretaker and PCP outside of her room, discussing my findings in conjunction with their own observations, and we came up with a plan of medication management. Her rigidity and contractures likely were secondary to her advanced Alzheimer disease. Her PCP had noted a mild elevation in some inflammatory markers, so we deemed a trial of low-dose steroids appropriate, since research has also shown steroids beneficial for such contractures. I pulled out my laptop and logged into their Wi-Fi to enter the electronic medical record. I typed up my note, which would be digitally sent to the PCP, and a simplified version of the recommendations for the patient, which her caretaker would be able to access via the patient portal. Marcus Welby, eat your heart out.

I am grateful for the advances made such that we can practice remotely, both for the safety of our patients and ourselves, though I have often missed the personal touch of being able to perform a physical exam and share space with the patient. A pat on the shoulder, sharing a knowing laugh with the patient when my cold hands make contact, and the self-deprecating jokes patients inevitably make as I examine the feet. For all the technology available at our disposal, at the heart of medicine is the patient-physician relationship. What has become common practice is that we have patients enter our medical home of the hospital or clinic. With the COVID-19 pandemic, the focus has shifted on meeting the patients where they are, typically in their living space via telemedicine, or, perhaps, even a home visit.

Today, the plague doctor's beak has evolved into an N-95 respirator and we've traded the waxed leather overcoat for surgical gowns. What we still share with that bygone era of soda jerks and rotary telephones goes as far back as parchment 
and papyrus: enduring values integral to the practice of medicine. Autonomy. Justice. Nonmaleficence. Beneficence. The Hippocratic Oath hanging in halls of hospitals and clinics maintains its roots firmly in those Greek physicians who came to their patients' bedside. While I felt like I was stepping into an anachronism in conducting a house call, in reality it was an extension of the timeless principles of care that undergird the practice of all physicians.

\section{References}

1. Kao H, Conant R, Soriano T, McCormick W. The past, present, and future of house calls. Clin Geriatr Med 2009;25:19.

2. Retief FP, Cilliers L. The evolution of hospitals from antiquity to the Renaissance. Acta Theologica 2010;26.

3. Mussap CJ. The plague doctor of Venice. Intern Med J 2019;49:671-676.

4. Fang LQ, Yang Y, Jiang JF, et al. Transmission dynamics of Ebola virus disease and intervention effectiveness in Sierra Leone. Proc Natl Acad Sci USA 2016;113: 4488-4493.

5. Meyer GS, Gibbons RV. House calls to the elderly: a vanishing practice among physicians. N Engl J Med 1997;337:1815-1820. 


\title{
Neurology
}

\author{
When duty house calls \\ Lealani Mae Y. Acosta \\ Neurology 2020;95;973-975 Published Online before print September 14, 2020 \\ DOI 10.1212/WNL.0000000000010864
}

This information is current as of September 14, 2020

Updated Information \& Services

References

Subspecialty Collections

Permissions \& Licensing

Reprints including high resolution figures, can be found at: http://n.neurology.org/content/95/21/973.full

This article cites 4 articles, 1 of which you can access for free at: http://n.neurology.org/content/95/21/973.full\#ref-list-1

This article, along with others on similar topics, appears in the following collection(s):

All Cognitive Disorders/Dementia

http://n.neurology.org/cgi/collection/all_cognitive_disorders_dementia Alzheimer's disease

http://n.neurology.org/cgi/collection/alzheimers_disease

Dementia aphasia

http://n.neurology.org/cgi/collection/dementia_aphasia

Dystonia

http://n.neurology.org/cgi/collection/dystonia

Information about reproducing this article in parts (figures,tables) or in its entirety can be found online at:

http://www.neurology.org/about/about_the_journal\#permissions

Information about ordering reprints can be found online:

http://n.neurology.org/subscribers/advertise

Neurology ${ }^{\circledR}$ is the official journal of the American Academy of Neurology. Published continuously since 1951 , it is now a weekly with 48 issues per year. Copyright @ 2020 American Academy of Neurology. All rights reserved. Print ISSN: 0028-3878. Online ISSN: 1526-632X.

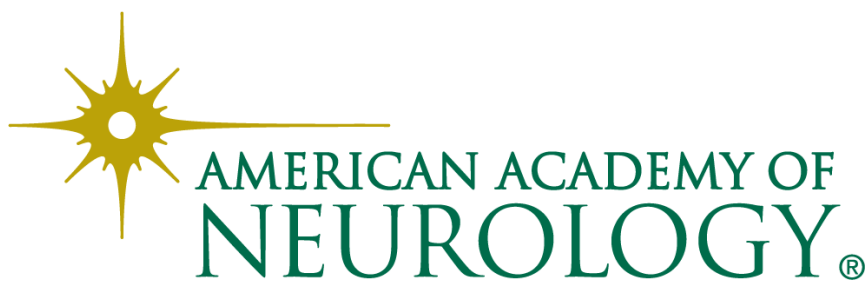

